A feminist teacher's account of her attempts to achieve the goals of feminist pedagogy

Geraldine McCusker

Manchester Metropolitan University, UK.

g.mccusker@mmu.ac.uk 


\section{A feminist teacher's account of her attempts to achieve the goals of feminist pedagogy}

This paper aims to interrogate some of the processes and tensions I faced in establishing a feminist space in a higher education institution in the UK context. The students I worked with needed to develop understanding of social justice concepts such as antidiscrimination and anti-oppression in order to progress from their undergraduate studies to a postgraduate professional qualification in social work. It was my contention that a feminist lens could support this understanding. The feminist space we established was informed by work in the field of feminist pedagogy, which supports the development of critical thinking that goes beyond the immediate learning context. Feminist pedagogy brings many rewards but also challenges and tensions, some of which I will explore in the paper. I will focus here on my efforts to establish and maintain this space, discussing what was achieved, and exploring the tensions involved when doing this in a neoliberal context, which as a depoliticized context, is a challenge to, and is challenged by, critical perspectives such as feminism.

\section{ESTABLISHING A FEMINIST CLASSROOM.}

Feminism is central to my practice in education; I draw on the work of other feminist teachers as I aim to create via my teaching '.. . a vision of what education might be like but frequently is not.' (Shrewsbury, 1997: 166). Carolyn Shrewsbury, who is recognised as a pioneer of feminist pedagogy (Raven, 2014) goes on to flesh out this vision, painting a picture of a classroom in which students and teachers work to achieve mutual goals both as a collective and as individuals. Feminist pedagogy gives emphasis to empowering students' voices, collaboration, community building, and validating knowledge based on experience (Kishimoto \& Mwangi, 2009), as it attempts to ensure the '... infusion of feminist values into the process and methods of teaching' (Forrest and Rosenberg, 1997: 179). Inevitably, such a goal results in a shift of emphasis in an educational setting: 
'When contemporary feminist movement made its initial presence felt in the academy there was both an ongoing critique of conventional classroom dynamics and an attempt to create alternative pedagogical strategies.' (hooks, 1994:180).

Feminist academic work is a challenge to traditional academic expectations. It tends to '... problematise traditional constructions of the academy.' (Leathwood and Hey, 2009:436) and '... has challenged the university with regard to everything from institutional practices like admissions to issues of curriculum and pedagogy.' (Bondy et al., 2015:3). Consequently, its development is not always supported (Weiler, 1995; Woodward \& Woodward, 2009). In addition, power relations in educational settings tend to mean that it gets marginalised (De Welde et al., 2013). This situation poses a challenge to the feminist teacher, but not one that is insurmountable, as in my practice; I have always found ways to imbue my teaching with my feminist values, despite managerialist practices in current universities that diminish teacher autonomy (Preston and Aslett, 2014; Gill and Donaghue, 2015). I take inspiration in this endeavour from others who seek to challenge sexism and other forms of discrimination in higher education settings. For example, the Women in Higher Education Management (WHEM) Network, an international feminist research forum that aims to support women in higher education management to succeed (Whemnetwork.com, 2016).

Like feminism, feminist pedagogy is not a monolithic and unitary concept; rather it is a movable, tractable and dynamic practice. There are multiple feminisms and multiple feminist pedagogies. Feminist pedagogies are diverse and multifaceted in nature with core goals of emancipation and liberation underpinning what is taught and how it is taught (Storrs and Mihelich, 1998). It is crucial to acknowledge that 'feminist pedagogy does not assume that all classrooms are alike.' (Shrewsbury, 1997:172), and the feminist classroom is a rich ecology rather than a monoculture (Coia and Taylor, 2013). This means that:

'....assuming a singular meaning to feminist pedagogy is ... problematic. Just as there are multiple feminisms, so there are multiple feminist pedagogies - for example, anti-racist feminist pedagogies, liberal feminist pedagogies, socialist feminist pedagogies, queer pedagogies, and intersectional feminist pedagogies.' (Briskin, 2015: 66). 
Feminist pedagogy takes many and varied approaches as it works to value the lives and experiences of women (Ropers-Huilman, 1998), and to encourage all students to '... participate in learning that values all humanity...' (Smith-Adcock et al., 2004:404). I recognise the varied and various strands that exist as feminist teachers practice in education, however I have opted to use the term 'feminist pedagogy' throughout this paper, rather than use the plural 'feminisms' and 'feminist pedagogies'. I do this as a personal choice; I prefer the use of it as a singular term to emphasise its contrast with other forms of pedagogy, and to underline the commonality of purpose of the various approaches it embraces. Many other authors have also opted for this singular terminology (Webb et al., 2002; Markowitz, 2006; Brown, 2009; Wang et al., 2011; Coia and Taylor, 2013; Light et al., 2015). Nevertheless, I stress that by using the singular term, I am not attempting to suppress the diversity of feminism or feminist pedagogy. I acknowledge that feminism embraces multiple subjectivities and positions and: '... in its political, practical and theoretical realms, represents divergent interpretations for many people.' (Brady and Dentith, 2001:165).

This diversity of approach has meant that although attempts at a definition of feminist pedagogy have been made, a neat statement on what it is has not been possible. It is not necessarily a checklist of teacher behaviours and strategies. However, it is a site that recognizes the complexity of identities, subjectivities, and social positions. It is an enabling, inspiring and motivating pedagogy that fosters resistance and encourages critical thinking (hooks ,1989; Lather, 1991; Morley ,1999 and Coia and Taylor, 2013; Light et al., 2015). It offers a challenge to mainstream pedagogical styles that can make women and other traditionally marginalised groups passive and invisible. As Frances Maher writing in the 1980s stated, in her critique of mainstream teaching styles of the time, 'women are silenced, objectified and made passive though both the course content and the pedagogical style of most college classrooms.' (Maher, 1985:31).

In setting itself this challenge, feminist pedagogy had affinities with the ideas of other critical pedagogues, many of whom frame their practice around the work of Paulo Freire ([1970] 1996) and Henri Giroux $(1988,2003)$. Critical pedagogy has its roots in the work of radical educators such as these, who aimed to establish a schooling system that emancipated those oppressed and disempowered. Critical pedagogues aim to provide 
space for critical engagement with divergent perspectives in order to support students from disenfranchised populations to understand the impact of capitalism, gender, race and homophobia on their lives (Darder et al., 2009). Clarke (2002:67) suggested:

'Teachers engaged in critical pedagogy are united in a view of education as a practice committed to the reduction, or even elimination, of injustice and oppression.'

Feminist pedagogy shares many of the ambitions of other critical pedagogies, and many authors have acknowledged the close ties between feminist pedagogy and critical or emancipatory pedagogies (Fisher, 1981; Maher, 1985; Currie, 1992; Shrewsbury, 1997; McClure, 2000; Markowitz, 2006 and Leach and Moon, 2008). Frances Maher admits feminist pedagogy's debt to previous critical thinkers when she says that it:

'... draws on the rich tradition ... of involving students in constructing and evaluating their own education.' (Maher, 1985:30).

Llewellyn and Llewellyn (2015: 14) also acknowledge that both share ' ... a desire to create "emancipatory" and "democratized" classrooms that challenge relations of domination'. In addition, Louise Morley has described feminist pedagogy as the: '...gender-sensitive development of earlier Marxist-influenced radical pedagogy.' (Morley, 1998:16). Feminist pedagogy attends to women's lives and oppression in a way that is not shared by other critical or socially just pedagogies (Gore,1993). 'Feminist pedagogy' was the label applied to the teaching methods employed as Women's Studies (now regularly referred to as Women's/Gender Studies) courses proliferated in universities across the UK, Canada and the USA in the 1970s (Kirkup and Whitelegg, 2013; Bondy et al., 2015). It emerged as a critical field in the 1980s with the intention of decentring androcentric theories and practices to enable a rethinking of teaching and learning (Nicholas and Baroud, 2015). Initially, fore-fronting gender was what mostly distinguished feminist pedagogy from other critical theories. As Shrewsbury (1997:167) said:

'At its simplest level, feminist pedagogy is concerned with gender justice and overcoming oppressions. It recognizes the genderedness of all social relations and consequently of all societal institutions and structures.' 
Subsequent characterisations have developed this to incorporate ideas about intersectionality, a key development within feminist pedagogy and its academic discipline of Women's Studies:

'Intersectionality requires the use of multiple categories of analysis, including purposeful reflection on how these categories intersect, work in conjunction, or grind against one another uneasily.' (Bondy et al., 2015:3)

An intersectional analysis enables an examination of multiple social identities and has made an important contribution to feminist thinking and understanding of gender (Shields, 2008).

Despite the inevitable issues entailed when trying to agree on a definition, and the wish to keep ideas about a feminist classroom fluid so as to avoid a hegemonic influence, there is a need to identify key characteristics in order to distinguish the feminist classroom from other classrooms in the institution. Hence many writers have come to an agreement about the main characteristics of feminist pedagogy, which can be summarised as movement towards: effecting social change, redefining pedagogical power and authority, valuing personal experience, diversity and subjectivity, reconceptualising classrooms as spaces for social justice, and using learning to help students to become activists and go beyond the classroom to effect the necessary wider changes that are needed (Omolade,1993; hooks, 1994; Weiler, 1995; Coate Bignell, 1996; Forrest and Rosenberg, 1997; Shrewsbury, 1997; Morley, 1998 ; Webb, et al ., 2002; Larson, 2005 and Coia and Taylor, 2013; and Light et al., 2015). Additionally, Lawrence (2016: online) offered the following as three key tenets of feminist pedagogy, 'Resisting hierarchy, Using experience as a resource, Transformative learning.'

Mindful of the representations offered in the literature on feminist pedagogy, I set about establishing a feminist space in my own work setting. This may be a useful juncture at which to clarify what I mean by 'a feminist classroom' in this context. It was not a physical space and did not happen in one arena. Rather it became all the interactions I had with the students who participated in the study. These interactions were sometimes semi - formal as we came together at my request, and at other times informal and impromptu as we interacted at their request, or in response to unexpected opportunities. One such opportunity was a successful bid to co-present our work at an academic conference at 
another UK university, an experience the students found to be enriching and informative. Strategies we employed varied, initially there was some formality as I took a lead role, and later sessions were more casual. In early encounters, I prepared materials that I believed would stimulate discussion. For example, we looked at the poetry of Audre Lorde and Maya Angelou. As these writers have inspired me, I wanted to share their work with the students. We also discussed meanings of concepts such as feminism, oppression, antidiscriminatory and anti-oppressive practices, and examined which examples from their experiences could be used to show insight into these concepts in an interview for a social work programme. Mindful of the need to avoid offering a narrative that suggests only Anglophone countries have developed this approach to equality debates, I introduced perspectives such as those of Chimamanda Ngozi Adiche. Ngozi Adiche (2014) writes about how her feminism developed as she progressed through her teenage years in Nigeria. I also encouraged students to share their understanding of feminism as a global perspective; this resulted in students with African heritage relating stories from their childhood. This was important because as Lawrence (2016) states, the wealth of USA literature on feminism and feminist pedagogy means it is easy to see work from the USA as the dominant narrative, but work from many other countries has also contributed to debate and enabled commonalities to be explored. For example, Wang et al., (2011) working in Taiwan discuss how a model of teaching based on poststructural feminist pedagogy had a positive effect on students' achievements and abilities to think critically.

The feminist space we created was not always an idyll or the safe haven that the summaries above might suggest. In reality, conflict, challenge and tension are also a part of the feminist classroom and the day-to-day practice of the feminist pedagogue, indeed: 'feminist classrooms can be intense spaces.' (Do Mar Pereira, 2012:128). For most feminist pedagogues, 'the inclusive, feminist classroom is one where there is a shared sense of struggle." (Leach and Moon, 2008: 65). This inevitably means that levels of both student and teacher comfort can fluctuate. Challenges also come from outside the classroom, from wider institutional structures and procedures. Before exploring some of these challenges to comfort levels, I will offer a brief pen picture of the student group from which the participants were drawn.

\section{The student cohort}


The students were in many ways non-traditional higher education students, reflecting the widening participation priority of consecutive UK governments since the early 2000s (Archer, et al., 2003; Pugh et al., 2005; David, 2011 and Ali, 2016). Although notions of equity deriving from the efforts of feminist activists and theorists have influenced this widening participation turn (David, 2011), this agenda has also appropriated feminist emancipatory concepts and operationalised them in ways that are often at odds with a feminist and truly emancipatory perspective.

The course that the students were following was an undergraduate BA in Social Care. Students on this course were predominantly women, many came from BAME (Black, Asian and Minority Ethnic) communities. The majority of students also came from disadvantaged backgrounds, and in each cohort a significant number were identified as needing a personal learning plan (PLP). These PLPs are more often than not for specific learning difficulties such as dyslexia and /or mixed anxiety and depression. Their course has close links to Social Work but does not provide a professional qualification in Social Work. In England, "Social Work" is a protected legal term; the role is regulated by the Health Care Professions Council (HCPC), who also approve the education and training of social workers (HCPC,2016). "Social Care" is a more generalised term for a number of roles within the care sector, both professional and many non-professional. In order to achieve social worker status, BA in Social Care students must study for a postgraduate qualification. Many of the students were interested in this route, but of course this would lead to another two years' of tuition fees, a factor that would have to be given careful consideration and in some cases might deter students from pursuing professional training.

\section{RECRUITING AND MAINTAINING STUDENTS IN THE FEMINIST CLASSROOM}

I wanted to create a feminist space to support the students who take the option of applying for postgraduate social work courses. The importance of more intimate classes for exploring key issues in social work have been acknowledged (Moulding, 2010), as such an environment better supports students to understand complex course content in which discussions of oppression are central (Santas, 2000). I had undertaken this support role informally in the past, at the request of students in previous cohorts. This work resulted in 
many fruitful discussions about the role of anti-oppressive and anti-discriminatory practices in social work, and the need for candidates being interviewed for social work training to be fully informed and show insight in these areas of practice.

A lack of engagement with and understanding of feminism as a perspective that could enhance understanding in these areas was something that seemed noteworthy to me as I undertook this work. The widening participation agenda that has resulted in so called 'non traditional' students entering universities, did not concentrate its ideas around gender equality (David, 2011). Consequently, it was not a surprise to me to find that feminist ideas are invisible or marginal in the lives of students in contemporary universities in the UK, and elsewhere, where discourses are shaped by neoliberal perspectives (Preston and Aslett, 2014; Gill and Donaghue, 2015).

I wanted to find ways to address this, so I decided that making this support more formal would create a fortuitous symmetry, as my need for data for my own research ambitions combined with their need for support with the social work application process. My research aims include making a contribution to feminist theory, knowledge and action, and developing strategies for feminist pedagogy. Along with Ropers-Huilman \& Winters (2011:667) I believe that:

'While feminist research is not a panacea for all issues in higher education, it has much to contribute to understanding and addressing the gendered contexts of colleges, universities, and educational policy.'

Feminist academic practice is useful for social work students as it has the ability to support students to '... develop critical approaches that ultimately contribute to equity and equality, within and beyond the academy.' (De Welde et al., 2013: 105). Larson (2005) has also identified feminist pedagogy's contribution to advancing social justice agendas through support of critical thinking and reflection. Such attributes are noted by many writers in the field of social work as essential for effective social work practice. (Dominelli, 2002; Fook, 2002; Gibbons and Gray, 2004 and Cooper, 2011). I strongly believe that a feminist lens contributes to an understanding of all inequalities (including ethnic and socioeconomic), as it enables a respect for people's diversity. Cree and Dean (2015) also argue that opening 
up conversations about feminism with social work students can contribute to social work's transformative aspirations.

The request for student volunteers yielded a group of 17 women, which eventually became 5 who continued with the whole project. Hereafter the 5 will be identified as P1 - P5. I tried to keep as many as possible engaged with the project, and spent time encouraging their continued participation in the research, and inviting them to be part of our feminist space. I did this with a concern at times about whether or not I was acting in a selfish, instrumental or exploitative manner, concepts that are at odds with feminist ideals. The following entry in my reflective diary reflects my anxieties here:

As a researcher I want to work with willing participants, I do not want to cajole or coerce people to participate, however, I need participants. How many times should I request participation? When is it bordering on harassment? I also need to get this project moving, but am I excluding some people because they have not responded within the deadlines I created? As a teacher to this group, I know they are not always responsive to emails, they miss key information at times, I cannot assume silence on their part to mean a lack of interest. Their lives are complex and at times chaotic. Which role should take precedence? Teacher? Researcher? The two do not need to be mutually exclusive; I am a feminist researcher, and a feminist teacher. If I close the door on participation I know some who will benefit will be excluded. Yet as a feminist it is important to give women's choices respect. Perhaps too I need to recognise their agency, at some point everyone who potentially could participate was invited, I cannot be responsible for decisions they make about emails that come in to their inboxes.

Although students had never explicitly said "No" I was mindful too of O'Connell Davidson's (2008:51) assertion and advice to accept and respect refusals:

'If researchers are working in a context that requires them to secure the consent of research participants, then they are expected to understand that 'No' definitely means 'No' if they meet with refusal.' 
I was also keenly aware that they might have been worried that a refusal may have implications for their grades. I made it very clear that it would not. I ensured I was very careful in how I requested their continued involvement, and at all times gave emphasis to the voluntary nature of it.

Another factor influencing levels of continued involvement with my project, from the students' perspective, was progress with their postgraduate social work applications. All of the twelve that opted out of the project also abandoned their postgraduate applications. Some did so after realising that they would not be able to afford to pursue postgraduate study, others after deciding that they preferred to concentrate on their undergraduate studies to achieve the best possible mark and perhaps would apply for Postgraduate study at a later date.

Nevertheless, in terms of my research, even though some students were no longer applying for social work training, I was still interested in their involvement for my project. I faced the dilemma of deciding who would benefit most if they were to continue with the project. I was conscious too of Paradis (2009:2) who asserted:

'Research is exploitative if the researcher's interests alone shape every step of the research process... and research resembles a colonial economy when researchers enter uninvited into the world of participants, extract a resource called data, process this resource into a product called theory, and use the product only for their own ends... On the other hand, transforming exploitative aspects of the traditional model can yield research that promotes the interests of marginalised people...'

I felt strongly that there were benefits for the students beyond the social work application and so the prospect of continuing with the group that we had established was offered to them. Some students maintained a partial engagement, but motivation did eventually dwindle. Again at this stage I had to tread carefully in terms of how many invites and reminders I would send out if they were not responding.

\section{The tensions and challenges we faced}


The feminist classroom too became a challenge to some of these students; a tension is inevitable if you turn traditional ways of teaching and learning on their head:

'...shifting paradigms or sharing knowledge in new ways challenges; it takes time for students to experience that challenge as positive.' (hooks, 1994: 42).

'The urge to experiment with pedagogical practices may not be welcomed by students who often expect us to teach in the manner they are accustomed to.' (hooks, 1994:142).

I was aware that for a small number of students the intimacy of the feminist space was not attractive. My interaction with these students had previously been as part of bigger groups of either 80 plus, or smaller seminar set ups of $25-30$. The students were not used to being invited to such an intimate space, the large class sizes that are part of the hegemonic neoliberal routine in universities limit opportunities for meaningful and critical discussion with students, and yet to engage on a deep level with critical perspectives such as anti-oppressive practice an intimate space is needed (Preston and Aslett, 2014). It was not surprising that some students found themselves uncomfortable in a smaller set up as they were used to more impersonal classes.

However, for those who remained, the familiarity and togetherness afforded by the small group arrangement did enable better engagement with critical thinking and anti-oppressive perspectives as the following participants' quotes indicate:

'I thought I had an understanding of inequalities, and discrimination, and oppression, but in reality I didn't, ... it was just a word, and then obviously you've given us a deeper understanding.' (P1)

'I think this has helped me realise where I have been discriminated against in my life... its made me understand that a lot more.' (P5) 
'... it makes me think about experiences of the past, and makes me aware I was under an oppressed situation... I didn't know it was an oppressed situation... now I have an understanding of what oppression is.' (P3)

'... when it's a big group and you have to move the discussion on, you're not able to help the penny drop in quite the same way.' (P4)

'... because its been a small group, and its been more relaxed, its been a safe space... you can mull things over, talk things over ...I think, its you know, more indepth.' (P1)

In addition, the power sharing that sits at the heart of feminist pedagogy was daunting for some. In all my interactions with students I aim to retain my feminist principles, but inevitable practicalities and organisational constraints mean that often I may take on an authority role. Initially students expected me to fulfill this role and looked to me for leadership. It is understandable that they may not be ready to shift their perceptions. Lesley Coia and Monica Taylor (2013) point out, 'In feminist classrooms, power is always negotiated. It moves around the classroom and it demands vigilance.' (Coia and Taylor, 2013: 6). However, power sharing is easier said than done, it requires a concerted effort. I believed I was ready to relinquish power but students were not always ready to receive it. Elizabeth Ellsworth has offered a stark warning to those of us who want to renegotiate power in our classrooms, arguing that there can be 'repressive myths' (Ellsworth, 1989: 308) in liberatory pedagogies, and inattention to them results in disempowerment and not the promised empowerment. I was aware that it is unfair to expect students to lead and exercise voice if such opportunities have not been afforded to them very often thus far. Nonetheless, the freedom to express one's views freely that a feminist space seeks to give women, was welcomed by some as the following quotes from two participants indicate as they compared our space with other sessions on the course:

'I probably would have thought of stuff but never said anything. I think through these classes and stuff it's given me more confidence in wanting to voice my opinion.' (P2) 
'... you kind of don't have to think before you speak, you can just speak and know that no one, it's not going to be judged...' (P2)

'...you could share with people and you knew that you weren't going to get judged for that.' (P4)

For many, voice is important in a feminist space, after all one of the goals of feminist pedagogy initially was '...to liberate the tortured voice.' (Juncker, 1988:428), and contribute to the '... disruption of power hierarchies which have kept women silent.' (Culley, 1985:213). Today this aim has changed in shape but coming to voice is still an area for work. I aimed to support empowerment and privilege voice (Webb et al., 2002), but in my dual role of teacher and researcher I had my own agendas and expectations. There were contradictions in our arrangement, I wanted to support the creation of a fluid space that eventually students would want to own, but I was also working to deadlines, as were the students in terms of their postgraduate applications. This entailed that some formality and structure had to be present, there were specific messages I needed to communicate to the group that would directly benefit them in the social work application processes, therefore a coherent and prepared script was necessary in early sessions. This meant that my voice dominated at times and students were silent early on. Student silence can be a useful site for examination, Ropers- Huilman (1996) argued silence does not have to be viewed with suspicion, powerful silences can exist. Like Orner (1992) she also advocates engaging with poststructural thought as a means to support better understanding of the multiple meanings of communication, and recognition that power can be expressed in a number of ways. Nevertheless, their silence bothered me, and I sought ways to encourage more interaction.

The uncertainties and unknowing of the feminist classroom meant I too had to make adjustments. I was now making myself available as source of support, so it was not surprising that the students cast me in a personal tutor role, (despite another colleague in the teaching team already having this role with them, and there being other support services available to them in the academy). Hence, I found myself supporting students with a number of personal and course-related issues. Perhaps the students were understandably seeking out support that was offered in a more personal and nurturing 
way. It has been noted that the neoliberal academy contradicts itself in that warm terms such as diversity, inclusion, wellbeing and support are widely used, but their expression is actually limited, and there is also a clear message often being given that coping should be based on personal resources rather than shared spaces (Gill and Donaghue, 2015).

I was happy to offer this support as it felt as though I was 'giving something back' and in doing so I was enacting my feminist value of reciprocity. However, as I was also asked to take on this role with students who had left the feminist classroom, I felt at times I was subject to unfair expectations. These students had declined the opportunity to share in the feminist space yet still expected my support; sadly, their instrumental approach was in many ways to be expected in the neoliberal context in which we were working:

'... rather than seeing the classroom as an active community with the potential for transformative learning, students may see it simply as one more cog in their degree completion.' (Preston and Aslett, 2014: 505).

I was also conscious that undertaking an unfair share of relational and interpersonal work is often expected of female teachers (Blackmore, 1996). Morley (1998) reported on the emotional labour involved in feminist teaching practices, identifying that it can lead to the teacher offering quasi-therapeutic services. She points out that often this is offered without resources and acknowledgment, and this and the blurring of boundaries entailed here take their toll on a feminist teacher. Such work is often invisible, unacknowledged, and time consuming, and in the neoliberal context where quantification and measurement are a priority, such work does not easily meet targets that management require. I wanted to avoid the: 'hidden injuries of the neoliberal university' (Gill, 2010:228), as I was acutely aware that my teacher style and research focus are on areas that are antagonistic to neoliberalism. Neoliberal discourses are unfavourable to women (Todd, 2016) and despite claims to the contrary, teaching has much lower priority in neoliberal organisations than research (Bal et al., 2014). Furthermore, as my research was connected to social justice concepts, a neoliberal academy constrains and challenges such a focus (Preston and Aslett, 2014); it also limits the critical engagement of both students and teachers as it restricts possibilities for teaching critical theory (Feigenbaum, 2007). Students as critical thinkers are not encouraged in a neoliberal context (Davies and Bansel, 2007 and 
Beckman et al., 2009). Consequently pedagogy that is critical or transformative is not promoted (Galpin, 2009 and Giroux, 2010).

\section{Does 'Feminism' put students off?}

The word 'feminism' also acted as a threat to some, at least one of the 12 that dropped out found my regular use of the word challenging. Even those that committed fully to the venture held negative views about feminism initially, as the following quotes exemplify:

'When I first thought of feminism I was thinking of the women that burnt their knickers... Mad women I suppose... when it came to voting I never wanted to vote... and she (my mother) was like, "Well women burnt their knickers for you, mad crazy women burnt their knickers for you, so you could vote."' (P5)

'I thought it was a dirty word ...' (P1)

'If someone would have accused me of being a feminist I would have run a mile and denied it.' (P1)

'There's a stigma attached to it.' (P4)

'I thought it was a derogatory label that you did not want to be associated with.' (P1)

In many ways, it is not surprising that these young women have not embraced feminism, given that their interpretation of it is in such negative terms. They could be said to be reflecting the individualism of what some call 'third wave feminism' (Walker, 1992 and Baumbardner and Richards, 2000) or a postfeminist view as they: '... seek to divorce themselves from the image of the unfeminine woman and anti-men sentiments.' (Gray and Boddy 2012: 382). 
I was conscious too that my personal introduction to feminism at the height of its so-called 'second wave' (Burns and Chantler, 2010; Gray and Boddy, 2010; Evans and Chamberlain, 2015 and David, 2016) was very different to the environment they were experiencing. For me feminism was a conscious decision and I join with Dale Spender who affirmed:

'My choice of feminism was a logical one, a deliberate decision on my part to improve the quality of my life. I selected feminism as a way of life, as a value system and a means of explaining the world and my place within it...' (Spender, 1986: 208).

Whatever their reasons for rejecting and disavowing feminism, their views certainly reflected a gulf between them and me. I wanted to traverse that gulf and find means to engage in meaningful discussions about feminism with them. Rational, productive and illuminating intergenerational discussions about feminism are possible as Woodward and Woodward (2009) demonstrated. As we progressed, I was heartened and reassured by the following 2 quotes from students:

'I think I'm becoming a feminist... the more I read back on everything I wrote I think, I do sound like a feminist actually.' (P5)

'I think it's the way I write now, just in my writing, because a lot of the things I wrote about in my blog ...I always read it back and always sound like l'm pro women.' (P2)

However, it was also evident to me that it was the White women in the group who were most receptive to feminism as we started to discuss it. This situation has resonance with Black feminists' critiques of the emphasis given to sisterhood and solidarity in Western feminism in the 1970s and early 1980s, which posit that a shared identity amongst all women is not a valid assumption. As we looked at the work of Audre Lorde I kept myself mindful of the following: 
'By and large within the women's movement today, white women focus upon their oppression as women and ignore differences of race, sexual preference, class, and age. There is a pretense (sic) to a homogeneity of experience covered by the word sisterhood that does not in fact exist.' (Lorde, [1984] 2000: 116).

Fortunately the students found Audre Lorde's work to be an inspiration as the following two quotes reflect:

'I have hope... it stands out for me, wow if she could go up to that level... you see somebody has done it before, you think I can as well, do it again...' (P3)

'Audre Lorde really inspired me as a woman.' (P5)

I did not want to support a space that denied any student their subjectivities. I was conscious that '...though all women are women, no woman is only a woman.' (Spelman, 1990: 187). I aimed therefore to be sensitive to critiques of feminism from Mohanty (1984) and Narayan (1997). Their work has enabled Western feminists to examine how practices might legitimize the West while colonising and othering the East. Narayan (1997) was also critical of attempts to impose and export a Western feminist agenda on women in developing countries. Crenshaw's (1991) concept of intersectionality ensures we are aware that our lives are not shaped by gender alone, and race, class, disability, and sexuality are examples of some of the other phenomena that coexist with gender and mean we are multiply constituted. Many feminist writers acknowledge this, King's concept of 'multiple jeopardy' (1988:42), hooks' 'interlocking systems of domination/oppression' (hooks, 1989: 175), and Hill Collins' discussion on the 'matrix of domination' (1990: 221), all reflect this type of understanding.

Sensitivity to the concept of intersectionality enables one to practice respect for the diversity of personal experience, again another area of potential challenge in a feminist classroom. Sometimes the personal experiences shared and conclusions drawn are at odds with feminist views. For example, at times views were expressed that valued and privileged Western practices above other cultures, and essentialist notions about women, 
motherhood and caring were often also articulated. I felt I needed to problematise such ideas but was mindful that as a white Western woman I did not have the same context as all of the students. I found it useful to remind myself that when in a leadership role, experiencing a pedagogy of discomfort (Boler, 1999) is necessary, as part of reflecting on one's own positions of dominance (Blackmore, 2010), and the following was also useful:

'feminist pedagogies ... demand critical examination of what lies below the surface. They demand confrontations with discontinuities, particularities, and the narratives that embody actual life stories.' (Greene,1992:x).

In these contexts and throughout the project, the empowerment that feminist pedagogy aspires to was a constant area I gave attention to.

'Empowering classrooms are places to practice visions of a feminist world, confronting differences to enrich all of us rather than to belittle some of us.' (Shrewsbury, 1997:169).

Fortunately, student comments also supported my belief that this principle had been achieved as the following signifies:

'Things have changed in my house though and everything... When I had my son I'd do everything and I really struggled. Now my boyfriend does more than me at home now, so I can tell when l've changed my way of thinking, my roles have also changed in the house as well... my boyfriend helps more, so it's really improved my life.' (P5)

'... now we have courage not to let them happen ... or at least put in strategies to take ourselves away from that situation.' (P1)

I'm a bit more passionate, l'd never really talk about it, but now... I was in a pub the other week, just with my family and my uncle said something and I was like you can't say that. Everybody was looking at me, like God, she's been reading too much at uni (sic)...' (P4) 


\section{CONCLUSION}

The feminist space we established in order to support more meaningful discussions about anti-discriminatory, anti-oppressive and feminist perspectives brought tensions and challenges, but also many enlightening and positive moments for all involved. The project supported the claim that feminist pedagogy offers opportunities to engage with students in a deeper and more satisfying way. It is a dynamic process of interaction that offers new possibilities in teaching and learning processes. It inevitably involves discomfort and challenge, as it requires constant monitoring of one's own values, positioning and practices. Tension is also created by the neoliberal context that currently has a hegemonic influence on UK universities (Gill and Donaghue, 2015), however these tensions have to be faced and navigated. Feminism as a perspective for practice in teaching and social work is a vital force that can support both fields to realise their transformative and emancipatory ambitions centred on eliminating injustice and oppression.

\section{$\underline{\text { References }}$}

Ali, A. (2016) 'Government will miss 'ambitious' 2020 higher education widening participation targets, report finds' The Independent [online] 4th April. [Accessed 30th June 2016].

Archer, L., Hutchings, M., \& Ross, A. with Leathwood, C., Gilchrist, R., \& Philips, D. (2003) Higher Education and Social Class: Issues of Exclusion and Inclusion. London: Routledge Falmer.

Bal, E., Grassiani, E., \& Kirk, K. (2014) Neoliberal individualism in Dutch universities: Teaching and learning anthropology in an insecure environment. Learning and Teaching, $7(3) 46-72$.

Baumbardner, J., \& A. Richards (2000) Manifesta: Young Women, Feminism and the Future. New York: Farrar, Strauss \& Giroux. 
Beckman, A., Cooper, C., \& Hill, D. (2009) Neoliberalization and managerialization of 'education' in England and Wales- A case for reconstructing education. Journal for Critical Education Policy Studies, 7, 311- 345.

Blackmore, J. (1996). Doing emotional labor in the educational market place: Stories from the field of women in management. Discourse, 17, 337-350.

Blackmore, J. (2010). Preparing leaders to work with emotions in culturally diverse educational communities. Journal of Educational Administration, 48, 642-658.

Boler, M. (1999). Feeling power. New York: Routledge.

Bondy, R., Nicholas, \& Light, T.P. (2015) Introduction: Feminist Pedagogy in Higher Education. In T.P. Light, J. Nicholas \& R. Bondy (Eds) (2015) Feminist Pedagogy in Higher Education: Critical Theory and Practice. Ontario: Wilfrid Laurier University Press.

Brady, J., \& Dentith, A. (2001) Critical Voyages: postmodern feminist pedagogies as liberatory practice.Teaching Education, 12(2), 165-176.

Briskin, L. (2015) Activist Feminist Pedagogies: Privileging Agency in Troubles Times. In T.P. Light, J. Nicholas \& R. Bondy (Eds) (2015) Feminist Pedagogy in Higher Education: Critical Theory and Practice. Ontario: Wilfrid Laurier University Press.

Brown, R.N. (2009) Black Girlhood Celebration: Toward a Hip-Hop Feminist Pedagogy. New York: Peter Lang Publishing Inc.

Burns, D., \& Chantler, K. (2010) Feminist Methodologies. In B. Somekh \& C.Lewin (Eds) Theory and Methods in Social Research $2^{\text {nd }}$ edition. New Delhi: Sage Publications India Pvt. Ltd.

Clarke, J. (2002) Deconstructing domestication: women's experience and the goals of critical pedagogy. In R. Harrison, F. Reeve, A. Hanson, \& J. Clarke (Eds) Supporting lifelong learning Volume 1: perspectives on learning. London: Routledge / Falmer and Open University.

Coate Bignell, K. (1996) Building Feminist Praxis Out Of Feminist Pedagogy: The Importance of Students' Perspectives. Women's Studies International Forum, 19(3), 315 325.

Coia, L., \& Taylor, M. (2013) Uncovering Our Feminist Pedagogy: A co/autoethnography. Studying Teacher Education, 9(1), 3 - 17.

Cooper, J. (2011) The need for more critically reflective social work [online] [Accessed 4th July 2016]

http://www.communitycare.co.uk/2011/04/08/the-need-for-more-critically-reflective-social$\underline{\text { workl }}$ 
Cree, V. E., \& Dean, J.S. (2015) Exploring social work students' attitudes towards feminism: opening up conversation. Social Work Education, 34(8), 903 - 920.

Crenshaw, K. (1991) Mapping the Margins: Intersectionality, Identity Politics, and Violence against Women of Color. Stanford Law Review, 43(6), 1241-1299.

Culley, M. (1985) Anger and Authority in the Introductory Women's Studies Classroom. In M. Culley \& C. Portuges (Eds) Gendered Subjects: The Dynamics of Feminist Teaching. Boston: Routledge and Kegan Paul $209-217$.

Currie, D.H. (1992) Subject-ivity in the classroom: Feminism meets academe. Canadian Journal of Education, 17, 341- 364.

Darder, A., Baltodano, M.P., \& Torres, R.D. (2009) The Critical Pedagogy Reader. New York: Routledge.

David, M. E. (2011) Changing concepts of equity in transforming UK higher education: implications for future pedagogies and practices in global higher education. Australian Education Research, 38, (January), $25-42$.

David, M.E. (2016) Reclaiming Feminism: Challenging Everyday Misogyny. Bristol: Policy Press.

Davies B., \& Bansel, P. (2007) Neoliberalism and Education. International Journal of Qualitative Studies in Education, 20, 247 - 259.

De Welde, K., Foote, N., Hayford, M., \& Rosenthal, M. (2013) Team teaching "gender perspectives": a reflection on feminist pedagogy in the interdisciplinary classroom. Feminist Teacher, 23(2), 105 - 120.

Do Mar Pereira, M. (2012) Uncomfortable classrooms: Rethinking the role of student discomfort in feminist teaching. The European Journal of Women's Studies, 19(1), 128 135.

Dominelli, L. (2002). Anti-oppressive social work: Theory and Practice. Basingstoke: Palgrave Macmillan.

Ellsworth, E. (1989) Why doesn't this feel empowering? Working through the repressive myths of critical pedagogy. Harvard Educational Review, 59(3), 297 - 324.

Evans, E., \& Chamberlain, P. (2015) Critical Waves: Exploring Feminist Identity, Discourse and Praxis in Western Feminism. Social Movement Studies, 14(4), 396 - 409.

Feigenbaum, A. (2007) The Teachable Moment: Feminist Pedagogy and the Neoliberal Classroom. The Review of Education, Pedagogy, and Cultural Studies, 29, 337-349. 
Fisher, B. (1981) What is feminist pedagogy? Radical Teacher, 18, 20 - 24.

Fook, J. (2002) Social Work: Critical Theory and Practice. London: Sage.

Forrest, L., \& F. Rosenberg, F. (1997) A review of the feminist pedagogy literature: The neglected child of feminist psychology. Applied and Preventive Psychology, 6, 179-192.

Freire, P. ([1970] 1996) Pedagogy of the Oppressed. Harmonsworth: Penguin.

Galpin, D. (2009) Who really drives the development of post-qualifying social work education and what are the implications of this? Social Work Education, 28, 65 - 80.

Gibbons, J. \& Gray, M. (2004) Critical thinking as integral to social work practice. Journal of Teaching in Social Work, 24, $19-38$.

Gill, R. (2010) Breaking the silence: The hidden injuries of the neoliberal university. In R. Flood, \& R. Gill (Eds) Secrecy and silence in the research process: Feminist reflections. London: Routledge.

Gill, R. \& Donaghue, N. (2015) Resilience, apps and reluctant individualism: Technologies of self in neoliberal academy. Women's Studies International Forum, 54, 91 - 99.

Giroux, H. A. (1988) Schooling and the Struggle for Public Life: Critical Pedagogy in the Modern Age. Minneapolis, MN: University of Minnesota Press.

Giroux, H. A. (2003) Public Pedagogy and the Politics of Resistance: Notes on a critical theory of educational struggle. Educational Philosophy and Theory, 35(1), 5- 16.

Giroux, H.A. (2010) Bare pedagogy and the politics of neoliberalism: Making the political more pedagogical. Policy Futures in Education, 2, 494 - 503.

Gore, J. (1993) The struggle for pedagogies: Critical and feminist discourses as regimes of truth. New York: Routledge.

Gray, M., \& Boddy, J. (2010). Making Sense of the Waves: Wipeout or Still Riding High? Affilia Journal of Women and Social Work, 25(4), 368 - 389.

Green, M. (1992) Foreword. In C. Luke \& J. Gore (Eds) Feminists and Critical Pedagogy. New York: Routledge.

HCPC (2016) Regulating, health, psychological and social work professions [online] [Accessed 24th November 2016] http://www.hcpc-uk.co.uk/aboutus/

Hill Collins, P. (1990) Black Feminist Thought: Knowledge, Consciousness, and the Politics of Empowerment. Boston: Unwin Hyman.

hooks, b. (1989) Talking Back: Thinking Feminist, Thinking Black. London: Sheba. 
hooks, b. (1994) Teaching to Transgress : Education as the Practice of Freedom. London: Routledge.

Juncker, C. (1988) Writing (with) Cixious. College English 50, 424 - 434

King, D. (1988) Multiple Jeopardy, Multiple Consciousness: The Context of a Black Feminist Ideology. Signs: Journal of Women in Culture and Society, 14(1), 42-72.

Kirkup, G. \& Whitelegg E. (2013) The legacy and impact of Open University women's Igender studies: 30 years on. Gender and Education, 25(1), 6 - 22.

Kishimoto, K. \& Mwangi, M. (2009) Critiquing the Rhetoric of "Safety" in Feminist Pedagogy: Women of Color Offering an Account of Ourselves. Feminist Teacher, 19(2), 87 $-102$.

Larson, L.M. (2005) The Necessity of Feminist Pedagogy in a Climate of Political Backlash. Equity and Excellence in Education, 38 (2), 135 - 144.

Lather, P. (1991) Getting Smart: Feminist Research and Pedagogy with/in the Post modern. London: Routledge.

Lawrence, E. (2016) Feminist Pedagogy [online] [Accessed 29th September 2016] http://www.genderandeducation.com/resources-2/pedagogies/feminist-pedagogy-2/

Leach, J. \& Moon, B. (2008) The Power of Pedagogy. London: Sage.

Leathwood, C. \& Hey, V. (2009) Gender/ed discourses and emotional subtexts: theorizing emotion in UK higher education. Teaching in Higher Education, 14(4), 429 - 440.

Light, T.P., Nicholas, J. \& Bondy, R. (Eds) (2015) Feminist Pedagogy in Higher Education: Critical Theory and Practice Ontario: Wilfrid Laurier University Press.

Llewellyn, K.R \& Llewellyn, J.J (2015) A Restorative Approach to Learning: Relational Theory as Feminist Pedagogy in Universities. In T.P. Light, J. Nicholas \& R. Bondy (Eds) (2015) Feminist Pedagogy in Higher Education: Critical Theory and Practice Ontario: Wilfrid Laurier University Press.

Lorde, A. ([1984] 2000) Sister Outsider: Essays and Speeches by Audre Lorde. Berkeley: Crossing Press.

Maher, F. (1985) Classroom pedagogy and the new scholarship on women. In M. Culley \& C.Portuges (Eds), Gendered Subjects: The Dynamics of Feminist Teaching. London and New York: Routledge and Kegan Paul. 
Markowitz, L. (2006) Unmasking moral dichotomies: can feminist pedagogy overcome student resistance? Gender and Education, 17(1), 39 - 55.

McClure, L. (2000) Paedagogus: Special section on Feminist pedagogy: Feminist pedagogy and the classics. The Classical World, 94(1), 53 - 55.

Mohanty, C.T. (1984) Under Western Eyes: Feminist Scholarship and Colonial Discourses. Boundary, 2, Spring / Autumn 12(3) /13(1) 333 -358.

Morley, L. (1998) All you need is love: feminist pedagogy for empowerment and emotional labour in the academy. International Journal of Inclusive Education, 2(1), 15 - 27.

Morley, L. (1999) Organising Feminisms: the Micropolitics of the Academy. Basingstoke: Macmillan.

Moulding, N.T. (2010) Intelligent design: Student perceptions of teaching and learning in large social work classes. Higher Education Research and Development, 29, 151 - 165.

Narayan, U. (1997) Dislocating Cultures: Identities, Traditions, and Third World Feminisms. London: Routledge.

Ngozi Adiche, C. (2014) We should all be feminists. London: Fourth Estate.

Nicholas, J. \& Baroud, J. (2015) Rethinking "Students These Days": Feminist Pedagogy and the Construction of Students. In T.P. Light, J. Nicholas \& R. Bondy (Eds) (2015) Feminist Pedagogy in Higher Education: Critical Theory and Practice. Ontario: Wilfrid Laurier University Press.

O'Connell Davidson, J. (2008). If no means no, does yes mean yes? Consenting to research intimacies. History of the Human Sciences, 21(4), 49 - 67.

Omolade, B. (1993) A Black Feminist Pedagogy. Women's Studies Quarterly, 21(3/4), 3138.

Orner, M. (1992) Interrupting the Calls for Student Voice in "Liberatory" Education: A Feminist Poststructural Perspective. In C.Luke \& J. Gore (Eds) Feminisms and Critical Pedagogy. New York: Routledge $74-89$.

Paradis, E. K. (2000). Feminist and community psychology ethics in research with homeless women. American Journal of Community Psychology, 28(6), 839-858.

Paradis, E.K. (2009). Ethics in Research with Homeless Women. In J.D. Hulchanski, P. Campsie, S. Chau, S.W. Hwang, \& E.K. Paradis (Eds.) Finding Home: Policy Options for Addressing Homelessness in Canada (e-book).

Preston, S. \& Aslett, J. (2014) Resisting Neoliberalism from within the Academy:

Subversion through an Activist Pedagogy. Social Work Education, 33(4), 502 - 518. 
Pugh, G., Coates, G., \& Adnett, N. (2005) Performance Indicators and Widening

Participation in UK Higher Education. Higher Education Quarterly, 59(1), 19 - 39.

Raven, S. (2014) Wanted: The Intersection of Feminist Pedagogy and Science Education. International Journal of Gender, Science and Technology, 6(2), 242 - 251.

Ropers - Huilman, B. (1996) Still Waters Run Deep: Meanings of Silence in Feminist Classrooms. Feminist Teacher, 10(1) 3 - 7.

Ropers-Huilman, B. (1998) Feminist teaching in theory and practice: Situating power and knowledge in poststructural classrooms. New York: Teachers College.

Ropers- Huilman, B. \& Winters, K.T.( 2011) Feminist Research in Higher Education. The Journal of Higher Education, 82(6), 667 - 690.

Santas, A, (2000) Teaching anti-racism. Studies in Philosophy and Education, 19, 349 361.

Shields, S.A. (2008) Gender: An Intersectionality Perspective. Sex Roles, 59, 301 - 311.

Shrewsbury, C.M. (1997) What Is Feminist Pedagogy? Women's Studies Quarterly, 25 (1/2), $166-173$.

Smith - Adcock, S., Ropers- Huilman, B. \& Hensley Choate, L. (2004) Feminist Teaching in Counselor Education: Promoting Multicultural Understanding. Journal of Multicultural Counseling and Development 32, 402 - 413.

Spelman, E. (1990). Inessential woman: problems of exclusion in feminist thought. London: The Women's Press.

Spender, D. (1986) What is Feminism? A Personal Answer. In J. Mitchell \& A. Oakley (Eds) What is Feminism? Oxford: Basil Blackwell.

Storrs, D. \& Mihelich, J. (1998) Beyond Essentialism: Team Teaching Gender and Sexuality. National Women's Studies Association Journal, 10(1), 98 - 118.

Todd, S. (2016) 'The university gender pay gap is down to neoliberal orthodoxy' The Guardian [online] 14th June. [Accessed 7th July 2016].

Walker, R. (1992) 'Becoming the third wave', in Ms Magazine 39, January/February.

Wang, Y., Chao, C.Y. \& Hung- Chang, L. (2011) Poststructural feminist pedagogy in English instruction of vocational and technical education. Higher Education, 61(2), 109 139. 
Webb, L.M., Allen, M.W. \& Walker, K.L. (2002) Feminist pedagogy: identifying principles. Academic Education Quarterly, 6, 67 - 72.

Weiler, K. (1995) Revisioning Feminist Pedagogy. National Women's Studies Association Journal, 7(2), 100- 106.

Whemnetwork.com. (2016) Women in Higher Education Management Network: About Us [online] [Accessed 24.11.16] http://whemnetwork.com.

Woodward, K. and Woodward, S. (2009) Why Feminism Matters: Feminism Lost and Found. London: Palgrave Macmillan. 